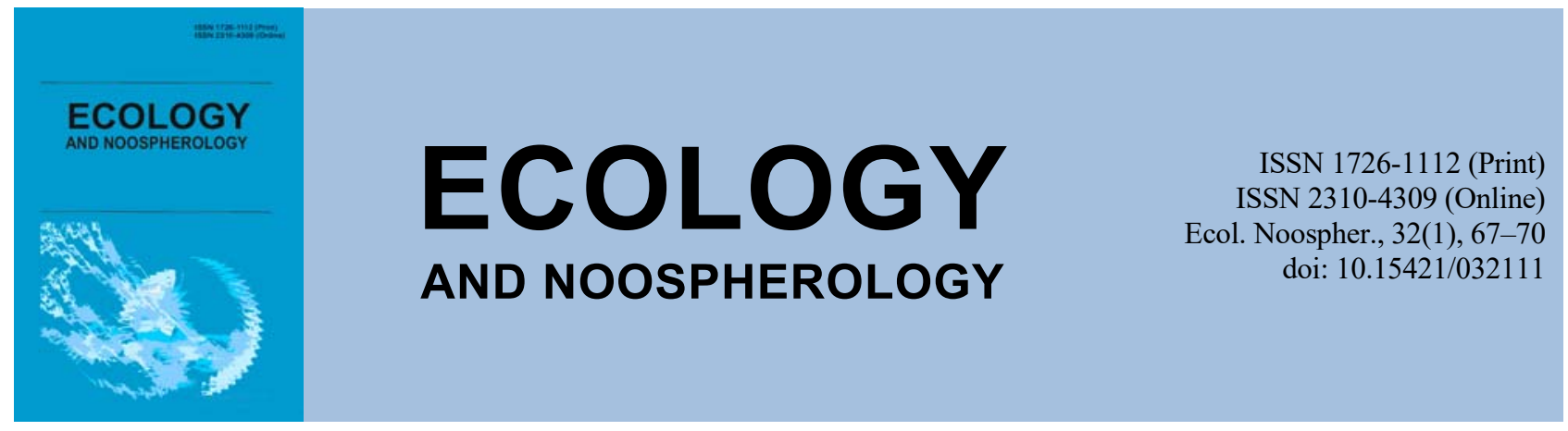

\title{
Antibiotic-resistant microbiota of water and soil ecosystems as risk factors for human health
}

\author{
T. Yu. Matylonok*, O. Ye. Pakhomov**, N. M. Polishchuck* \\ *Zaporizhzhia State Medical University, Zaporizhzhya, Ukraine \\ **Oles Honchar Dnipro National University, Dnipro, Ukraine
}

Article info

Received 15.04.2021

Received in revised form 19.04.2021

Accepted 14.05.2021

Zaporizhzhia State Medical University, Mayakovsky ave., 26, Zaporizhzhya, 69000, Ukraine.

Tel.: +38-097-069-51-22

E-mail:

tetyana.kopteva@gmail.com

Oles Honchar Dnipro

National University

Gagarin Ave., 72, Dnipro,

49010, Ukraine.

\begin{abstract}
Matylonok, T. Yu., Pakhomov, O. Ye, Polishchuck, N. M. (2021). Antibiotic-resistant microbiota of water and soil ecosystems as risk factors for human health. Ecology and Noospherology, 32(1), 67-70. doi:10.15421/032111
\end{abstract}

Bacterial resistance to antibiotics is one of the three major health challenges of the $21 \mathrm{st}$ century. One of the most important reasons for the acquisition and spread of antibiotic resistance in the environment is the irrational and uncontrolled use of antibacterial drugs, not only for medical but also other purposes, and their improper disposal. The microbiome of aquatic and soil ecosystems is characterized by the acquisition of antibiotic resistance through mobile genetic elements, contact with antibacterial drugs and their residues, the action of heavy metals and environmental stress. Also, according to the literature, it is noted that the resistance of microorganisms to antibacterial drugs in the environment existed much earlier than in clinical strains. These facts can not help but worry, because antibiotic-resistant strains of the environment have an extremely negative impact on human health. Once in the human body with water and food, they significantly complicate and / or make it impossible to further treat life-threatening diseases. Also, antibacterial residues circulating in aquatic and soil ecosystems, entering the human body can cause cancer, allergic reactions or disruption of the natural intestinal microflora. These ecosystems are characterized by large-scale spread of antibiotic-resistant microorganisms, antibacterial drugs and their residues. The aim of our work was to analyze with the help of theoretical methods of scientific research the reasons for the acquisition and spread of antibiotic resistance among environmental microbiota, namely in aquatic and soil ecosystems. To determine the impact of antibiotic-resistant bacteria of these ecosystems on human health. We have found that antibacterial drugs, antibiotic-resistant strains and resistance genes are a particular problem for wastewater treatment. Antibiotics can provide a selective load, as the mechanisms that break them down can promote resilience and selectively enrich. Wastewater treatment plants can be a favorable factor for the horizontal transfer of genes and the development of bacterial polyresistance, and high-resistance genes can be preserved even after disinfection. Soil is also an important reservoir for antibiotic-resistant bacteria and resistance genes. Microorganisms are in a constant struggle for existence in this ecosystem and try to colonize the micro-scale with the most favorable for their ecotype habitat. Antibiotic-resistant soil bacteria are in close contact with other members of the microbiota, which in turn promotes the horizontal transfer of resistance genes, even between cells of different species or genera through genetic determinants. Conclusion: ecosystems are characterized by large-scale spread of antibiotic-resistant microorganisms, antibacterial drugs and their residues. Therefore, this problem should be properly addressed, as the presence of antibiotic-resistant microorganisms, antibacterial drugs and their residues in the environment can cause unpredictable environmental consequences and adversely affect human health with more severe incurable infectious diseases. Monitoring programs for antibioticresistant microorganisms and resistance genes in soil and aquatic ecosystems are necessary and very relevant today. After all, this microbiota poses a serious threat to both the environment and human health and can easily spread from one part of the world around the world.

\section{Антибіотикорезистентна мікробіота водної та грунтової екосистем як чинники ризику небезпеки для здоров'я людини}




\title{
Т. Ю. Матильонок*, О. С. Пахомов**, Н. М. Поліщук*
}

\author{
*Запорізький державний медичний університет, Запоріжж, Украӥна \\ **Дніпровський національний університет імені Олеся Гончара, Дніпро, Україна
}

Стійкість бактерій до антибіотиків відноситься до однієї із трьох серйозних проблем охорони здоров'я XXI століття. Найважливішою причиною набуття та поширення антибіотикорезистентності у навколишньому середовищі $\epsilon$ нераціональне та неконтрольоване застосування антибактеріальних препаратів, не лише в медичних, але й інших цілях, та неналежна їх утилізація. Мікробіому водної та грунтової екосистем властиве придбання антибіотикорезистентності за допомогою мобільних генетичних елементів, контакту 3 антибактеріальними препаратами та їх залишками, дії важких металів та екологічного стресу. Також згідно з літературними даними резистентність мікроорганізмів до антибактеріальних препаратів навколишнього середовища існувала набагато раніше, ніж у клінічних штамів. Ці факти не можуть не турбувати, адже антибіотикорезистентні штами навколишнього середовища вкрай негативно впливають на здоров'я людини. Потрапляючи в організм людини 3 водою та їжею, вони значно ускладнюють та/або унеможливлюють в подальшому надання лікування небезпечних для життя людини захворювань. Доведено, що антибактеріальні залишки, які циркулюють у водній та грунтовій екосистемах, потрапляючи в організм людини, можуть спричинити розвиток раку, алергічних реакцій або порушення природної мікрофлори кишечника. Для грунтової та водної екосистем характерне широкомасштабне розповсюдження антибіотикорезистентних мікроорганізмів, антибактеріальних препаратів та їх залишків, що, у свою чергу, може спричинити непередбачувані екологічні наслідки та негативно вплинути на здоров'я людини 3 більш тяжкими невиліковними інфекційними захворюваннями.

Ключові слова: антибіотикорезистентність; гени резистентності; навколишнє середовище, антибактеріальні препарати

\section{Вступ}

Виникнення та поширення антибіотикорезистентності є однією з глобальних проблем як для медичної спільноти, так і для охорони екологічної системи загалом. ВООЗ віднесла проблему поширення антибіотикорезистентності до однієї із трьох найбільш серйозних загроз громадської охорони здоров'я XXI століття (Sokolova et al., 2021). Причиною значного збільшення рівня антибактеріальних препаратів і швидкості їх поширення у навколишньому середовищі $\epsilon$ надмірне та неправильне використання антибіотиків не лише для надання лікування хворим, а й в немедичних цілях (Serwecińska, 2020). Так, за $\begin{array}{lllll}\text { результатами } \mathrm{CDC} & (2017 & \text { р.), майже } 50 \quad \%\end{array}$ антибактеріальних препаратів використовуються не за призначенням та/або передозуванням (Belding, Boopathy, 2018). Масове та широкомасштабне зловживання антибактеріальними препаратами пришвидшує еволюцію антибіотикорезистентних бактерій та взаємообмін генами резистентності до антибіотиків у навколишньому середовищі (Serwecińska, 2020). Наприклад, за літературними джерелами, висвітлюється поширення в різних екосистемах гену резистентності до колістину MCR в ізолятах Escherichia coli, Enterobacter, Klebsiella, Proteus, Salmonella, Citrobacter, Pseudomonas, Acinetobacter, Kluyvera, Aeromonas, Providencia i Raulotella (Anyanwu et al., 2020). Даний фактор підвищує ризик передачі екологічного резистому людині (Serwecińska, 2020). У багаточисленних дослідженнях описується важлива роль навколишнього середовища в круговороті антибіотикорезистентності в природі. Причиною може бути як виникнення механізмів стійкості до антибактеріальних препаратів в екологічних бактеріях, так і забруднення навколишнього середовища коменсалами та патогенами людини і тварин (Vaz-Moreira et al., 2014). Залишки антибактеріальних препаратів у навколишньому середовищі здійснюють множинний згубний вплив на мікробіоту. Субінгібуючі концентрації даних речовин можуть виступати сигнальними молекулами та викликати здвиг в експресії, передачі та модуляції активності генів вірулентності, формуванні біоплівок і сприйнятті кворуму. Вживання забруднених антибактеріальними залишками води i сільськогосподарських продуктів може спричинити вкрай негативні наслідки для здоров'я людини, а саме призвести до розвитку раку, алергічних реакцій або порушення природної мікрофлори кишечника (Serwecińska, 2020).
Мета роботи - проаналізувати за допомогою теоретичних методів наукового дослідження причини набуття та поширення антибіотикорезистентності серед мікробіоти навколишнього середовища, а саме у водній та грунтовій екосистемах. Визначити вплив антибіотикорезистентних бактерій даних екосистем на здоров’я людини.

Одним із найважливіших біотопів знаходження бактерій на Землі $\epsilon$ вода. Вона може являти собою джерело генів резистентності, бути підсилювачем та/або резервуаром даних генів, що потрапили у воду iз забрудненнями, або дійсно бути як біореактор, що полегшує обмін генами резистентності між бактеріями (Vaz-Moreira et al., 2014). Антибактеріальні препарати та їх біоактивні метаболіти потрапляють у водну екосистему через міські стічні води та агроекосистему. Екотоксичні з'єднання високо розчинні у воді, тому швидко поширюються у водній та грунтовій екосистемах (Serwecińska, 2020). За літературними джерелами, антибіотики виявлялись у стічних водах багатьох розвинених країн, таких як Китай, Німеччина, Велика Британія, Японія, Швейцарія, Італія, США та ін. За дослідженнями різних авторів, найвища концентрація (від декількох сотень і навіть тисяч мг/дм ${ }^{3}$ ) та найбільший різновид антибіотиків (більш ніж 100 різних фармацевтичних препаратів) визначались у стічних водах фармацевтичних підприємств. Варто наголосити, що окрім антибіотиків, у стічних водах фармацевтичних підприємств виділялись як антибіотикорезистентні мікроорганізми, так і гени резистентності (Sokolova et al., 2021; Lykov et al., 2020). У ряді раніше проведених досліджень зразків води на південному сході Луїзіани показується, що постійно були присутні ген erm (B), який відповідає за резистентність до еритроміцину, специфічні гени Sul1, tet (A) і tet (W), що обумовлюють стійкість до сульфонаміду та тетрацикліну (Belding, Boopathy, 2018). Для водоочисних підприємств антибактеріальні препарати, антибіотикорезистентні штами та гени резистентності, що виявляються в стічних водах, складають особливу проблему. Антибіотики можуть надавати селективне навантаження, адже механізми, що розкладають їх, можуть сприяти розвитку стійкості та вибірково збагачуватись. Очисні споруди можуть бути сприятливим фактором для горизонтального передання генів та розвитку полірезистентності бактерій, а гени резистентності на високому рівні можуть зберігатись навіть після дезінфекції (Pruden et al., 2013). За результатами проведених 
досліджень авторів, в очисних спорудах Мілану виявлялось від $20 \%$ до $47 \%$ резистентних до ампіциліну E. coli та від $16 \%$ до $25 \%$ ампіцилінрезистентних загальних гетеротрофних бактерій (Ghernaout et al., 2020). Оскільки процеси очищення води не здатні повністю видалити ці небезпечні фактори, люди можуть піддаватися ïx впливу через купання, водні види спорту, сільськогосподарське зрошення та споживання продуктів харчування (Amarasiri et al., 2020).

Грунт також $\epsilon$ важливим резервуаром стійких до антибіотиків бактерій та генів резистентності. Грунт представлений різнорідністю мікробіому, у ньому відмічається просторова неоднорідність складу мікроорганізмів 3 великою генетичною різноманітністю, здатністю продукувати молекули антибіотиків (Nesme, Simonet, 2015) та наявністю різноманітних складних механізмів самозахисту від власних же антибіотиків. Майже завжди разом 3 генами біосинтезу антибіотиків згруповані генетичні детермінанти саморезистентності, тому їх експресія спільно регулюється (Peterson, Kaur, 2018). Мікроорганізми знаходяться у постійній боротьбі за існування в даній екосистемі та намагаються колонізувати мікромасштаби 3 найбільш сприятливим для їх екотипу середовищем проживання (Nesme, Simonet, 2015). Наприклад, бактеріальні групи рекреаційних піщаних пляжів відзначаються значним різноманіттям видового складу та можуть негативно впливати на баланс між громадським здоров'ям та екологією. За проведеними дослідженнями авторів, найбільш домінуючими в зразках узбережжя Південної Африки виявлялись Proteobacteria, Firmicutes, Actinobacteria, Bacteroidetes та Gemmatimonadetes. Загалом, за таксономічним аналізом було виділено 1163 роди бактерій i у всіх зразках ідентифіковано ген резистентності до поліміксину. Дані показники можуть призвести до високого ризику зараження при тісному контакті людей з послабленим імунітетом (Sibanda, Ramganesh, 2021). Антибіотикорезистентні бактерії грунту знаходяться в тісному контакті з іншими представниками мікробіоти, що, у свою чергу, сприяє горизонтальній передачі генів резистентності, навіть між клітинами різних видів чи родів за допомогою генетичних детермінант (Serwecińska, 2020; Kunhikannan et al., 2021). 3 огляду на те що грунт постійно взаємодіє зі всіма компонентами біосфери, мікроорганізми мають можливість широко розповсюджуватись у навколишньому середовищі.

Крім того, згідно із сучасними дослідженнями, відомо, що пул генів резистентності до антибактеріальних препаратів еволюційно раніше розпочав своє існування у навколишньому середовищі, тобто раніше існував, ніж серед клінічних штамів (Nesme, Simonet, 2015). Існують докази того, що деякі клінічно значимі гени резистентності виникли саме від мікробіоценозу навколишнього середовища. Так, Д’Коста та його колеги виявили в зразках вічної мерзлоти Аляски віком 30 тис. років молекули ДНК iз сильною нуклеотидною гомологією 3 генами антибіотикорезистентності (Nesme, Simonet, 2015; Wright, $2010)$. Генетичну різноманітність $\beta$-лактамаз, що широко зустрічається в клінічних закладах, також у раніше проведених дослідженнях виділяли разом 3 багатьма іншими алельними варіантами в глибоководних відкладеннях підводної гори Едісон (Nesme, Simonet, 2015). Допускається, що як захисний механізм проти грибкових продуцентів $\beta$-лактама бактерії грунту набувають фермент $\beta$-лактамази та за допомогою горизонтального переносу генів широко розповсюджують його серед мікробних таксонів (Cytryn et al., 2017). У забруднених поверхневих водах може циркулювати ген резистентності NDM-1, який надає бактеріям резистентність до значної кількості антибактеріальних препаратів (Pruden et al., 2013).

Доведено, що непатогенні бактерії навколишнього середовища можуть передавати ген резистентності клінічним штамам. Наприклад, ген CTX-M ESBL патогенних бактерій майже ідентичний гену CTX-M непатогенних екологічних видів Kluyvera; детермінанта стійкості до хінолонів qnr у Klebsiella походить від геному непатогенних видів Vibrio та Shewanella; aph6 ген хромосоми Acinetobacter guillouiae, що існує в навколишньому середовищі, тотожний до плазмиди резистентності $A$. baumannii, мікроорганізмів родини Enterobacteriaceae та роду Pseudomonas (Peterson, Kaur, 2018). Бактеріям, що циркулюють у навколишньому середовищі, характерне генетичне передання антибіотикорезистентності між різними штамами за допомогою мобільних генетичних елементів, таких як плазміди, інтегрони, транспозони (Kunhikannan et al., 2021).

Гени резистентності до антибактеріальних препаратів відіграють ряд важливих ролей для грунтових сапрофітних бактерій, а саме від реакції на вироблення антибіотиків до фізіологічних функцій бактеріальних клітин. Циркуляція генів резистентності між різними господарями формує структури мікробної популяції та спричиняє значний вплив на екологію, адаптацію і генетичну диверсифікацію бактерій (Nesme, Simonet, 2015). Так, за результатами досліджень грунту в Нідерландах, спостерігалось збільшення генів резистентності з 1970 року по 2008 рік у 15 разів (Belding, Boopathy, 2018). Також припускається, що посилення екологічного стресу може призводити до збільшення виробництва антибіотикоподібних з'єднань у грунтових бактерій, що, у свою чергу, може призвести до виникнення та поширення антибіотикорезистентності (Brevik et al., 2020).

Антибіотики та їх метаболіти в результаті вкрай широкого використання накопичуються у зростаючих концентраціях як у водних, так і наземних екосистемах. Концентрація антибактеріальних препаратів в грунті може коливатись від декількох нанограмів до 50 мг/кг грунту. Даний фактор може призвести до виникнення антибіотикорезистентності мікробіоти навколишнього середовища, адже існують докази того, що навіть низька концентрація антибіотика може викликати зміни в геномі мікроорганізмів. Різні класи антибактеріальних препаратів можуть бути причиною порушення балансу екосистеми в результаті зміни структури та функціональності мікрофлори грунту та води (Orlewska et al., 2018; Baquero et al., 2008). Антибіотики здатні як руйнувати екосистему, так і змінювати властивості симбіотичних бактерій, які стрімко перетворюються в патогени 3 високою вірулентністю (Matalygina, 2020).

Крім того, за даними літературних джерел, на формування антибіотикорезистентності у навколишньому середовищі впливає концентрація важких металів, оскільки атмосфера сприяе спільному відбору резистентності до важких металів та антибактеріальних препаратів. Забруднення навколишнього середовища важкими металами підвищує рівень толерантності мікроорганізмів до антибактеріальних препаратів за рахунок спільної регуляції генів стійкості (Nath et al., 2019). Мікроорганізми здатні протистояти стресу важких металів та переносити навіть значні їх концентрації за допомогою різноманітних механізмів, а саме блокуванням бар'єрів проникнення, внутрішньоклітинної та позаклітинної секвестрації, активного транспорту, ферментативної детоксикації i зниження чутливості клітинних мішеней до йонів металів. Ця здатність сприяє відбору антибіотикорезистентних штамів навіть у чистому водному середовищі 3 потенційним ризиком поширення даної резистентності патогенам людини (Squadrone, 2020; Moghannem et al., 2015).

\section{Висновки}

Програми моніторингу антибіотикорезистентних мікроорганізмів та генів резистентності в грунтовій та водній екосистемах необхідні і вельми актуальні для 
сьогодення. Адже дана мікробіота складає серйозну небезпеку як для навколишнього середовища, так і для здоров'я людини і може з легкістю поширюватись із однієї частини світу по всій планеті. Наприклад, вперше у 2008 р. виділені в Індії «супербактерії», що експресують білок метало- $\beta$-лактамази- 1 , для сьогодення складають глобальну проблему. Виявлена у 2015 році резистентність до колістину в наш час реєструється в більш ніж 50 країнах на п'яти континентах (McCann et al., 2019). Гени резистентності не лише залишаються в різних природних матрицях, але й мігрують, трансформуються, поширюються i дифундують в інші біотопи навколишнього середовища. I, як результат, вони дестабілізують навколишнє середовище, потрапляють в харчовий ланцюг, впливають на здоров'я людини $(\mathrm{Li}$, Zhang, 2020). Тому інформаційно-просвітницька робота, проведення моніторингу антибіотикорезистентної мікробіоти у грунтовій та водній екосистемах є життєво важливими заходами, що спрямовані на обмеження поширення забруднення навколишнього середовища та збереження біорізноманітності, екосистеми та здоров'я людини.

\section{References}

Amarasiri, M., Sano, D., Suzuki, S. (2020) Understanding human health risks caused by antibiotic resistant bacteria (ARB) and antibiotic resistance genes (ARG) in water environments. Current knowledge and questions to be answered, Critical Reviews in Environmental Science and Technology, 50(19), 2016-2059.

Anyanwu, M. U., Jaja, I. F., Nwobi, O. C. (2020). Occurrence and characteristics of mobile colistin resistance (mcr) genecontaining isolates from the environment: a review. International journal of environmental research and public health, 17, 1028 .

Baquero, F., Martínez, J. L., Cantón, R. (2008). Antibiotics and antibiotic resistance in water environments. Current opinion in biotechnology, 19(3), 260-265.

Belding, C., Boopathy, R. (2018). Presence of antibioticresistant bacteria and antibiotic resistance genes in coastal recreational waters of southeast Louisiana, USA //Journal of Water Supply: Research and Technology-AQUA, 67, 800-809.

Brevik, E. C., Slaughter, L., Singh, B. R., Steffan, J. J., Collier, D. (2020). Soil and Human Health: Current Status and Future Needs. Air, Soil and Water Research, 13, 1-23.

Cytryn, E., Markiewicz, Z., Popowska, M. (2017). Antibiotics and antibiotics resistance genes dissemination in soils. Antibiotics and Antibiotics Resistance Genes in Soils. Springer, Cham, 151-190.

Ghernaout, D. (2020). Removing antibiotic-resistant bacteria (ARB) carrying genes (ARGs): challenges and future trends. Open Access Library Journal, 7(1), 1.

Kunhikannan, S. Thomas, C., Franks, A., Mahadevaiah, S. (2021). Environmental hotspots for antibiotic resistance genes. MicrobiologyOpen. 10, 1194-1197.

Li, Q., Zhang, Q. (2020). Prevalence and pollution characteristics of antibiotic resistant genes in one high anthropogenically-impacted river. PLOS ONE, 15(4), $\underline{\mathrm{e} 0231128 .}$
Lykov, I., Kusacheva, S., Safronova, M., Loginova, A. (2020). Environmental Pollution by Pharmaceuticals. Ecology and Industry of Russia, 24(8), 51-55 (in Russian).

Matalygina, O. A. (2020). Antibiotikorezistentnost kak shirokii i mnogogrannyi biologicheskii fenomen. Meditcina: teoriia i praktika, 5(3), 39-44 (in Russian).

McCann, C. M. (2019). Understanding drivers of antibiotic resistance genes in High Arctic soil ecosystems. Environment international, 125, 497-504.

Moghannem, S. A., Refaat, B., El-Sherbiny, G., El-Sayed, M., Elsehemy, I., Kalaba, M. H. (2015). Characterization of heavy metal and antibiotic-resistant bacteria isolated from polluted localities in Egypt. Egyptian Pharmaceutical Journal, 14, 158-165.

Nath, S., Paul, P., Roy, R. (2019). Isolation and identification of metal-tolerant and antibiotic-resistant bacteria from soil samples of Cachar district of Assam, India. SN Appl. Sci., $\underline{1,727 .}$

Nesme, J., Simonet, P. (2015). The soil resistome: a critical review on antibiotic resistance origins, ecology and dissemination potential in telluric bacteria. Environmental microbiology, 17(4), 913-930.

Orlewska, K., Markowicz, A., Piotrowska-Seget, Z., SmoleńDzirba, J., Cycoń, M. (2018). Functional Diversity of Soil Microbial Communities in Response to the Application of Cefuroxime and/or Antibiotic-Resistant Pseudomonas putida Strain MC1. Sustainability, 10(10), 3549.

Peterson, E., Kaur, P. (2018) Antibiotic resistance mechanisms in bacteria: relationships between resistance determinants of antibiotic producers, environmental bacteria, and clinical pathogens. Frontiers in microbiology, 9, 2928.

Pruden, A., Larsson, D. G., Amézquita, A., Collignon, P., Brandt, K. K., Graham, D. W. (2013). Management options for reducing the release of antibiotics and antibiotic resistance genes to the environment. Environmental health perspectives, 121(8), 878-885.

Serwecińska, L. (2020). Antimicrobials and antibiotic-resistant bacteria: a risk to the environment and to public health. Water, 12(12), 3313.

Sibanda, T., Ramganesh, S. (2021) Taxonomic and functional analyses reveal existence of virulence and antibiotic resistance genes in beach sand bacterial populations. Archives of Microbiology, 203 (4), 1753-1766.

Sokolova, L. I., Galchenko, D. S., Smirnova, M. G., Blinovskaia, Ia. Iu. (2021). Ispolzovanie prirodnykh aliumosilikatov dlia ochistki stochnykh vod ot antibiotikov razlichnykh klassov [The use of natural aluminosilicates for wastewater treatment from antibiotics of various classes]. Gidrometeorologiia i ekologiia, 62, 113-126 (in Russian).

Squadrone, S. (2020). Water environments: metal-tolerant and antibiotic-resistant bacteria. Environ Monit Assess, 192, 238.

Vaz-Moreira, I., Nunes, O. C., Manaia, C.M. (2014). Bacterial diversity and antibiotic resistance in water habitats: searching the links with the human microbiome. FEMS microbiology reviews, 38(4), 761-778.

Wright, G. D. (2010). Antibiotic resistance in the environment: a link to the clinic? Current opinion in microbiology, 13(5), 589-594. 